\title{
Disruption of the $\mathrm{CRF}_{2}$ Receptor Pathway Decreases the Somatic Expression of Opiate Withdrawal
}

\author{
Francesco Papaleo ${ }^{1,4}$, Sandy Ghozland ${ }^{2}$, Manuela Ingallinesi', Amanda J Roberts ${ }^{2}$, George F Koob ${ }^{3}$ and \\ Angelo Contarino*,I \\ 'Unité de Nutrition et Neurosciences, Universités Bordeaux I et Victor Segalen Bordeaux 2, Talence, France; ${ }^{2}$ Molecular and Integrative \\ Neurosciences Department, The Scripps Research Institute, La Jolla, CA, USA; ${ }^{3}$ Committee on the Neurobiology of Addictive Disorders, The \\ Scripps Research Institute, La Jolla, CA, USA
}

\begin{abstract}
Escape from the extremely aversive opiate withdrawal symptoms powerfully motivates compulsive drug-seeking and drug-taking behaviors. The corticotropin-releasing factor (CRF) system is hypothesized to mediate the motivational properties of drug dependence. CRF signaling is transmitted by two receptor pathways, termed $\mathrm{CRF}_{1}$ and $\mathrm{CRF}_{2}$. To investigate the role for the $\mathrm{CRF}_{2}$ receptor pathway in somatic opiate withdrawal, in the present study we used genetically engineered mice deficient in the $\mathrm{CRF}_{2}$ receptor $\left(\mathrm{CRF}_{2}-1-\right)$. We employed a novel, clinically relevant mouse model of 'spontaneous' opiate withdrawal as well as a classical opioid receptor antagonist (naloxone)-precipitated opiate withdrawal paradigm. To induce opiate dependence, mice were treated with intermittent escalating morphine doses $\left(20-100 \mathrm{mg} / \mathrm{kg}\right.$, i.p.). We found that $8-128 \mathrm{~h}$ after the last opiate injection, $\mathrm{CRF}_{2}-1-$ mice showed decreased levels of major somatic signs of spontaneous opiate withdrawal, such as paw tremor and wet dog shake, as compared to wild-type mice. Similarly, challenge with naloxone $2 \mathrm{~h}$ after the last morphine injection induced lower levels of paw tremor and wet dog shake in $\mathrm{CRF}_{2}-1-$ mice as compared to wild-type mice. Despite the differences in somatic signs, wild-type and $\mathrm{CRF}_{2}-/$ - mice displayed similar plasma corticosterone responses to opiate dosing and withdrawal, indicating a marginal role for the hypothalamus-pituitary-adrenal axis in the $\mathrm{CRF}_{2}$ receptor mediation of opiate withdrawal. Our results unravel a novel role for the $\mathrm{CRF}_{2}$ receptor pathway in opiate withdrawal. The $\mathrm{CRF}_{2}$ receptor pathway might be a critical target of therapies aimed at alleviating opiate withdrawal symptoms and reducing relapse to drug intake.

Neuropsychopharmacology (2008) 33, 2878-2887; doi:I 0.1038/npp.2008.8; published online 20 February 2008
\end{abstract}

Keywords: drug dependence; opiate withdrawal; CRF system; $\mathrm{CRF}_{2}$ receptor; mice

\section{INTRODUCTION}

Opiate dependence is a chronic, relapsing disorder with a major impact on public health. Recent reports show an alarming rise in the recreational use of opiate drugs among adolescents, indicating that the incidence rate of opiate dependence may dramatically increase in the next years (NIDA, 2005; OEDT, 2006). In opiate-dependent individuals, heroin 'highs' are followed by a severe opiate withdrawal syndrome composed of somatic signs and symptoms, and negative affective states (O'Brien, 1996). Besides a positive reinforcement theory of drug addiction (Shaham et al, 2003), studies indicate that avoidance of,

*Correspondence: Current address. Dr A Contarino, Unité de Nutrition et Neurosciences, Universités Bordeaux I et Victor Segalen Bordeaux 2, Avenue des Facultés-Bâtiment B2, Talence 33405, France, Tel: + 33 (0)5 575717 04, Fax: + 33 (0)5 400027 76,

E-mail: angelo.contarino@nppda.u-bordeaux2.fr

${ }^{4}$ Current address: Clinical Brain Disorders Branch, National Institute of Mental Health, NIH, 10 Center Drive, Bldg I0, Room 4N312, Bethesda, MD 20892-1385, USA.

Received 9 August 2007; revised 19 November 2007; accepted 10 January 2008 and/or escape from, the extremely aversive opiate withdrawal symptoms powerfully motivates compulsive opiateseeking and opiate-taking behavior (Carrera et al, 1999; Kenny et al, 2006; Lu et al, 2005; Schulteis and Koob, 1996). The opiate withdrawal syndrome is currently treated mainly by drugs mimicking opiate action, such as methadone (Gonzalez et al, 2004; Kreek et al, 2002). Opiate-like drugs have greatly ameliorated the management of opiate withdrawal and dependence. However, the abrupt discontinuation of such medications is often followed by relapse into another cycle of opiate abuse and dependence (Kreek et al, 2002). The development of novel treatments thus remains a major goal and relies heavily on the understanding of the neural mechanisms underlying the opiate withdrawal syndrome.

The corticotropin-releasing factor (CRF) system is a major coordinator of endocrine and behavioral responses to stress (Heinrichs et al, 1994; Rivier and Vale, 1983). The CRF system might also mediate the motivational properties of drug dependence. CRF receptor antagonists reduce stress-induced reinstatement of drug-seeking behavior and ameliorate negative affective-like states associated with alcohol, cocaine, or opiate withdrawal (Erb et al, 1998; 
Sarnyai et al, 1995; Stinus et al, 2005; Valdez et al, 2002b). The latter studies point to the CRF system as a promising target of novel and effective therapies for drug dependence. In mammals, CRF signaling is mediated by two receptor pathways, termed $\mathrm{CRF}_{1}$ and $\mathrm{CRF}_{2}$ (Hauger et al, 2003). Genetically engineered mouse models have allowed the discovery of distinct and often opposite functions for the two known CRF receptor pathways (Bale and Vale, 2004; Contarino and Gold, 2002). In particular, $\mathrm{CRF}_{1}$ receptordeficient mice display decreased hypothalamus-pituitaryadrenal (HPA) axis as well as behavioral reactions to stressors (Contarino et al, 1999; Muller et al, 2003; Smith et al, 1998; Timpl et al, 1998). In net contrast, $\mathrm{CRF}_{2}$ receptor-deficient mice show increased HPA axis and affective-like responses to stressors (Bale et al, 2000; Bale and Vale, 2003; Coste et al, 2000, 2006; Kishimoto et al, 2000). In line with a major role for the $\mathrm{CRF}_{1}$ receptor pathway in stress-responsive circuitry, we found that genetic disruption of the $\mathrm{CRF}_{1}$ receptor pathway eliminated the negative affective-like states of opiate withdrawal (Contarino and Papaleo, 2005). However, in net contrast to affective-like indices, disruption of the $\mathrm{CRF}_{1}$ receptor pathway exacerbated the somatic expression of opiate withdrawal (Papaleo et al, 2007). Thus, our previous studies indicate a complex physiopathological role for the $\mathrm{CRF}_{1}$ receptor pathway in opiate dependence. However, the role for the $\mathrm{CRF}_{2}$ receptor pathway in opiate dependence remains largely unexplored.

To examine the specific contribution of the $\mathrm{CRF}_{2}$ receptor pathway to somatic opiate withdrawal signs, in the present study we used $\mathrm{CRF}_{2}$ receptor-deficient mice (Bale et al, 2000). For this purpose, we employed a clinically relevant mouse model of opiate withdrawal recently developed in our laboratory (Papaleo and Contarino, 2006) as well as a classical opioid receptor antagonist-precipitated opiate withdrawal paradigm (Matthes et al, 1996).

\section{MATERIALS AND METHODS}

\section{Subjects}

Group-housed, littermate female mice on a mixed C57BL/ 6Jx129 background that were wild-type or $\mathrm{CRF}_{2}$ receptornull mutant $\left(\mathrm{CRF}_{2}-\mathrm{l}-\right)$ were used throughout (Bale et al, 2000). Mice were 4-5 months old at the time of the experiments and derived from mating $\mathrm{CRF}_{2}+/-$ mice. Wild-type and $\mathrm{CRF}_{2}-I-$ offspring of $\mathrm{CRF}_{2}+/-$ breeders were identified by PCR analysis of tail DNA. The mice were housed in a colony room maintained at $22 \pm 2^{\circ} \mathrm{C}$ on a 12 -h light/dark cycle (lights on from 0800 hours until 2000 hours). Mice used in the naloxone-precipitated opiate withdrawal study were group-housed in a reversed cycle room, with lights on from 2000 hours until 0800 hours, and opiate withdrawal tests were conducted during the dark phase of the 12-h light/dark cycle. Food and water were available ad libitum. All studies were conducted in accordance with the National Institute of Health Guide for the Care and Use of Laboratory Animals and the European Communities Council Directive of 24 November 1986 (86/ 609/EEC), and were approved by the local Animal Care and Use Committee.

\section{Experimental Procedures}

The spontaneous opiate withdrawal study was carried out in the Laboratoire Homéostasie-Allostasie-Pathologie (EA 3666), University of Bordeaux, France. During the 5 days preceding the beginning of drug injections, the mice were handled every other day for $1 \mathrm{~min}$ for a total of three times. During the following 6 days, wild-type and $\mathrm{CRF}_{2}-I-$ mice were treated every $12 \mathrm{~h}$ (0800 and 2000 hours) with increasing doses of morphine according to the following protocol: day 1: $20 \mathrm{mg} / \mathrm{kg}$; day 2: $40 \mathrm{mg} / \mathrm{kg}$; day 3: $60 \mathrm{mg} / \mathrm{kg}$; day 4: $80 \mathrm{mg} / \mathrm{kg}$; day 5: $100 \mathrm{mg} / \mathrm{kg}$; day $6: 100 \mathrm{mg} / \mathrm{kg}$; only one injection in the morning. Then, the mice were tested daily $8,32,56,80,104,128$, and $152 \mathrm{~h}$ after the last morphine injection. For this purpose, mice were individually placed into transparent Plexiglas cylinders (diameter: $23 \mathrm{~cm}$, height: $50 \mathrm{~cm}$ ) and observed continuously for $30 \mathrm{~min}$ for the occurrence of somatic signs of opiate withdrawal. The opioid receptor antagonist-precipitated opiate withdrawal study was carried out at the Molecular \& Integrative Neurosciences Department, The Scripps Research Institute (La Jolla, CA, USA). The mice were injected with vehicle or morphine as in the spontaneous opiate withdrawal study, and $2 \mathrm{~h}$ after the last injection, they were treated with naloxone $(1 \mathrm{mg} / \mathrm{kg})$. The mice were individually placed into transparent plastic cylinders (diameter: $30 \mathrm{~cm}$, height: $60 \mathrm{~cm}$ ) placed on blotting paper $15 \mathrm{~min}$ before the naloxone injection and observed continuously for the occurrence of somatic signs of opiate withdrawal up to $30 \mathrm{~min}$ after the naloxone injection.

Jumps, paw tremors, wet dog shakes, body stretches, and sniffing were counted as the number of events occurring during the total test time (graded signs); chewing, teeth chattering, diarrhea, body tremor, piloerection, and palpebral ptosis were instead recorded as the number of 5-min intervals in which it occurred (checked signs, maximal score $=6$ ). Body weights (BWs) were recorded each time the mice were injected as well as immediately before and after the 30-min opiate withdrawal tests, and the percentage of BW changes was calculated. To obtain a comprehensive index of the severity of somatic opiate withdrawal including all of the signs examined, for each mouse a global opiate withdrawal score was calculated by summing the raw values of somatic signs (Gellert and Holtzman, 1978).

\section{Evaluation of the HPA Axis Activity during Opiate Treatment and Withdrawal}

Another cohort of wild-type and $\mathrm{CRF}_{2}-1-$ mice was treated with increasing doses of morphine $(20-100 \mathrm{mg} / \mathrm{kg}$; i.p.), as described above. Just prior to (12-h opiate withdrawal) and 30 and $90 \mathrm{~min}$ after the last opiate injection, three tail blood samples were collected from each mouse. Furthermore, $8 \mathrm{~h}$ after the last morphine injection, wild-type and $\mathrm{CRF}_{2}-\mathrm{I}-$ mice were tested for somatic opiate withdrawal signs, as described above, and blood was collected from the trunk immediately thereafter. Plasma samples were stored at $-20^{\circ} \mathrm{C}$ until corticosterone assay. Plasma corticosterone levels were quantified by radioimmunoassay using a specific corticosterone antibody (ICN Pharmaceuticals). The intraand interassay coefficients of variation were approximately 3.5 and $8 \%$, respectively. 


\section{Drugs}

Morphine $\mathrm{HCl}$ (20-100 mg/kg, i.p.; Francopia, Gentilly, France) and naloxone $\mathrm{HCl}(1 \mathrm{mg} / \mathrm{kg}$, s.c.) were dissolved in physiological saline and injected in a volume of $10 \mathrm{ml} / \mathrm{kg}$ of BW. Control mice were injected with the same volume of saline.

\section{Statistical Analysis}

A two-way analysis of variance (ANOVA) with genotype (wild-type or $\mathrm{CRF}_{2}-/-$ ) as a between-subject factor and time as a within-subject repeated measure factor was used to examine percentage of $\mathrm{BW}$ loss during the intermittent morphine injections and the 30 -min somatic opiate withdrawal tests carried out $8-152 \mathrm{~h}$ after the last morphine injection, the percentage of BW recovery following discontinuation of opiate treatment and plasma corticosterone levels being measured just prior to and 30 and 90 min after the last morphine injection. Graded somatic signs of opiate withdrawal were subjected to the Lilliefors test for normality using the Statistica software; data that did not follow a normal distribution were analyzed by the non-parametric Mann-Whitney $U$-test, whereas data that showed normal distributions were examined by parametric tests (eg, ANOVA). Thus, paw tremor, wet dog shake, body stretch, and global opiate withdrawal scores observed during each 30 -min test of the spontaneous opiate withdrawal study as well as jump and sniffing of the naloxone-precipitated opiate withdrawal test were analyzed by the Mann-Whitney $U$-test. Paw tremor, wet dog shake, global opiate withdrawal scores, and percentage of BW loss observed during the naloxone-precipitated opiate withdrawal test were analyzed by a two-way ANOVA with genotype (wild-type, $\mathrm{CRF}_{2}-$ I-) and treatment (vehicle, morphine) as independent variables. The Student-Newman-Keuls post hoc test was used for individual group comparisons. Checked somatic signs of opiate withdrawal were analyzed by the Mann-Whitney $U$-test. The accepted value for significance was $P<0.05$. For illustration purposes, data analyzed by non-parametric statistics were represented as median (lower, upper quartiles), whereas data analyzed by parametric statistics were represented as mean \pm SEM.

\section{RESULTS}

Disruption of the $\mathrm{CRF}_{2}$ Receptor Pathway Decreases the Somatic Expression of Spontaneous Opiate Withdrawal

In mice, the abrupt discontinuation of chronic opiate administration is followed by a constellation of somatic signs, such as jumping (escape attempt), paw tremor, wet dog shake, body stretch, diarrhea, chewing, teeth chattering, and palpebral ptosis (Papaleo and Contarino, 2006).

Prior to the beginning of morphine dosing, BWs were $29.6 \pm 2.0$ or $28.4 \pm 0.6 \mathrm{~g}$ (mean \pm SEM) for wild-type or $\mathrm{CRF}_{2}-/-$ mice, respectively $(P=\mathrm{NS}$, Student's $t$-test $)$. Twice-daily treatment with increasing morphine doses caused a progressive BW loss. Analysis of percent BW loss revealed no genotype effect $\left(\mathrm{F}_{1,16}=1.09, P=\mathrm{NS}\right)$, a time effect $\left(\mathrm{F}_{5,80}=114.81, \quad P<0.0001\right)$, but no genotype $\times$ time interaction effect $\left(\mathrm{F}_{5,80}=0.99, P=\mathrm{NS}\right)$. Intermittent morphine administration produced comparable BW loss in wild-type and $\mathrm{CRF}_{2}-/-$ mice (Supplementary Figure 1a). Also, following morphine discontinuation, wild-type and $\mathrm{CRF}_{2}-/-$ mice displayed similar $\mathrm{BW}$ recovery $\left(\mathrm{F}_{1,16}=0.00\right.$, $P=$ NS; Supplementary Figure 1b).

Starting $8 \mathrm{~h}$ after the last morphine injection, the mice were tested every $24 \mathrm{~h}$ for the occurrence of somatic opiate withdrawal signs. Analysis of somatic signs of opiate withdrawal revealed that $\mathrm{CRF}_{2}-/-$ mice displayed less paw tremors than wild-type mice $8 \mathrm{~h}(U=2.0, P<0.001)$, $32 \mathrm{~h} \quad(U=12.5, P<0.05)$, 56h $(U=12.0, \quad P<0.05), 80 \mathrm{~h}$ $(U=12.5, P<0.05)$, and $104 \mathrm{~h}(U=15.5, P<0.05)$ after the last morphine injection (Figure 1a). Furthermore, $\mathrm{CRF}_{2}-\mathrm{I}-$ mice made less wet dog shakes than wild-type mice $32 \mathrm{~h}$ $(U=17.5, P<0.05), 56 \mathrm{~h}(U=16.0, P<0.05), 104 \mathrm{~h}(U=9.5$, $P<0.005)$, and $128 \mathrm{~h}(U=18.0, P<0.05)$ after the last opiate injection (Figure $1 \mathrm{~b}$ ). Throughout the repeated 30 -min tests carried out 8-152 h after the last morphine injection, genetic inactivation of the $\mathrm{CRF}_{2}$ receptor pathway did not affect the expression of opiate withdrawal-induced body stretch ( $U=27.5-38.5, P=\mathrm{NS}$; data not shown), palpebral ptosis ( $U=29.0-38.5, P=\mathrm{NS}$; data not shown), chewing $(U=$ 24.0-39.0, $P=\mathrm{NS}$; Figure 2a), and diarrhea $(U=22.0-40.0$, $P=\mathrm{NS}$; Figure 2b). Also, during the repeated tests, wildtype and $\mathrm{CRF}_{2}-\mathrm{I}-$ mice displayed similar $\mathrm{BW}$ losses $\left(\mathrm{F}_{1,16}=0.31, P=\mathrm{NS}\right.$; data not shown $)$.

Analysis of global opiate withdrawal scores revealed that $8 \mathrm{~h} \quad(U=7.0, P<0.005), 32 \mathrm{~h} \quad(U=11.0, P<0.01), 56 \mathrm{~h}$ $(U=9.0, P<0.01), 80 \mathrm{~h}(U=9.0, P<0.01), 104 \mathrm{~h}(U=10.0$, $P<0.01)$, and $128 \mathrm{~h}(U=11.0, P<0.01)$ after the last morphine injection, $\mathrm{CRF}_{2}-/-$ mice displayed lower levels of global opiate withdrawal than opiate-withdrawn wildtype mice (Figure 3 ). Genotypes did not differ $152 \mathrm{~h}$ after the
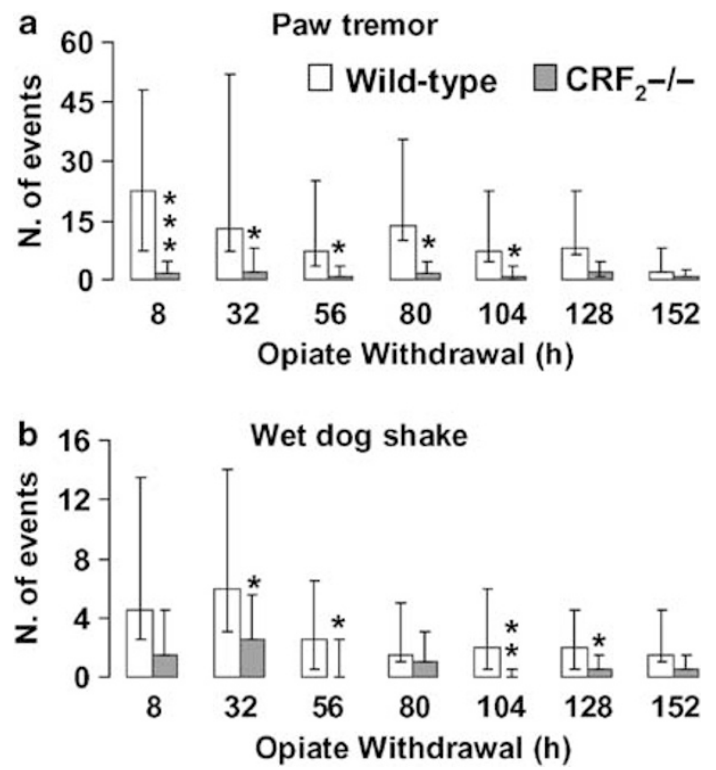

Figure I Discrete graded somatic signs of spontaneous opiate withdrawal. (a) Paw tremors and (b) wet dog shakes displayed by opiatewithdrawn wild-type or $\mathrm{CRF}_{2}-1-$ mice during repeated daily 30-min tests carried out 8-152 h after the last morphine injection. Values represent the median (lower, upper quartile). $N=8-10$ per genotype. $* P<0.05$, ** $P<0.005$, **** $P<0.001$ vs opiate-withdrawn wild-type mice at the same time point. 

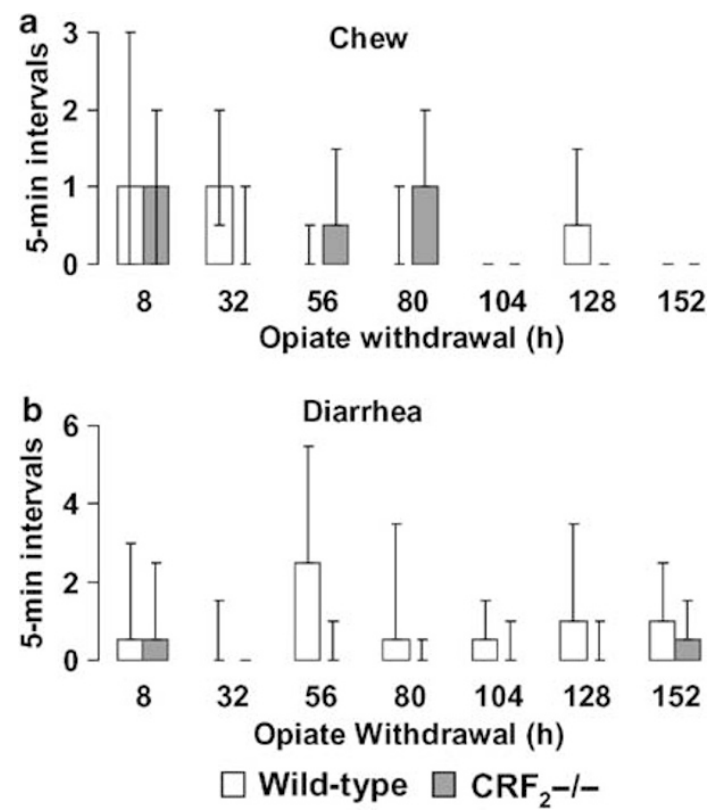

Figure 2 Discrete checked somatic signs of spontaneous opiate withdrawal. (a) Chews and (b) diarrhea displayed by opiate-withdrawn wild-type or $\mathrm{CRF}_{2}-1$ - mice during repeated daily 30-min tests carried out $8-152 \mathrm{~h}$ after the last morphine injection. Values represent the median (lower, upper quartile). $N=8-10$ per genotype.

last opiate administration ( $U=28.0, P=\mathrm{NS}$; Figure 3). Thus, at least up to $128 \mathrm{~h}$ after the last morphine injection, $\mathrm{CRF}_{2}-\mathrm{I}-$ mice displayed reduced levels of spontaneous somatic opiate withdrawal as compared to wild-type mice.

\section{Unaltered Plasma Corticosterone Responses to Opiate Dosing and Withdrawal in $\mathrm{CRF}_{2}$ Receptor-Deficient Mice}

Analysis of plasma corticosterone levels measured just prior to (12-h opiate withdrawal) and 30 and 90 min after the last morphine injection revealed no genotype effect $\left(\mathrm{F}_{1,10}=0.88\right.$, $P=\mathrm{NS})$, a time effect $\left(\mathrm{F}_{2,20}=61.28, P<0.0001\right)$, but no genotype $\times$ time interaction effect $\left(\mathrm{F}_{2,20}=1.18, P=\mathrm{NS}\right)$, indicating that $\mathrm{CRF}_{2}$ receptor deficiency did not affect HPA axis activity related to either opiate dosing or withdrawal (Figure 4a). Notably, plasma corticosterone levels were higher 30 and $90 \mathrm{~min}$ after than prior to morphine injection (eg, during opiate withdrawal, $P<0.0005$; Figure 4a). Plasma corticosterone levels were also measured immediately after a 30-min spontaneous opiate withdrawal test carried out $8 \mathrm{~h}$ after the last morphine injection. Similar to the above, opiate-withdrawn $\mathrm{CRF}_{2}-1-$ mice displayed less paw tremors $(U=3.0$, $P<0.05)$, wet $\operatorname{dog}$ shakes $(U=6.0, P=0.05)$, and lower global opiate withdrawal scores $(U=3.0, P<0.05)$ than opiate-withdrawn wild-type mice (data not shown). However, at the end of the behavioral test, opiate-withdrawn $\mathrm{CRF}_{2}-\mathrm{I}-$ and wild-type mice showed similar plasma corticosterone levels $\left(t_{10}=1.54, P=\mathrm{NS}\right.$; Student's $t$-test $)$, ruling out a role for the HPA axis in the $\mathrm{CRF}_{2}$ receptorregulated expression of somatic opiate withdrawal (Figure 4b). Notably, plasma corticosterone levels detected immediately after the 30-min somatic opiate withdrawal test

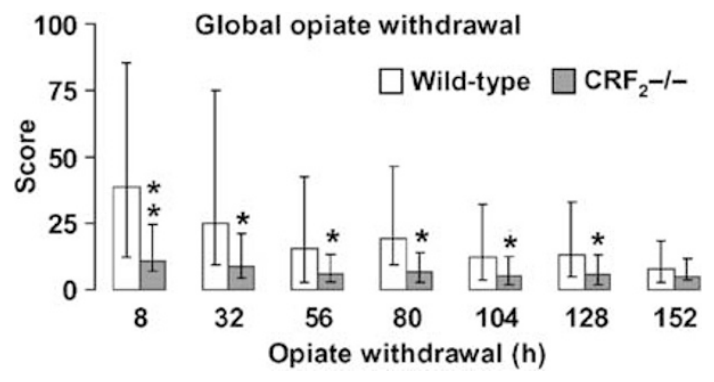

Figure 3 Global score of spontaneous somatic opiate withdrawal. Comprehensive scores (sum of the somatic sign values) displayed by opiate-withdrawn wild-type or $\mathrm{CRF}_{2}-1$ - mice during repeated daily 30min tests carried out $8-152 \mathrm{~h}$ after the last morphine injection. Values represent the median (lower, upper quartile). $N=8-10$ per genotype. ${ }^{*} P<0.01,{ }^{*} * P<0.005$ vs opiate-withdrawn wild-type mice at the same time point.

were higher than those observed just prior to the last morphine injection (12-h opiate withdrawal), most likely due to an opiate withdrawal-linked HPA axis response to behavioral testing (for comparisons, see Figure $4 \mathrm{a}$ and $\mathrm{b}$ ).

\section{Disruption of the $\mathrm{CRF}_{2}$ Receptor Pathway Decreases the Somatic Expression of Naloxone-Precipitated Opiate Withdrawal}

Two hours after the last vehicle or morphine injection, wildtype and $\mathrm{CRF}_{2}-I-$ mice were challenged with naloxone $(1 \mathrm{mg} / \mathrm{kg}$, s.c.) and immediately tested for the occurrence of somatic signs of opiate withdrawal. Examination of graded signs revealed a genotype $\times$ opiate treatment interaction effect for paw tremor $\left(\mathrm{F}_{1,23}=4.99, P<0.05\right)$. Opiate-treated wild-type mice made more paw tremors than vehicle-treated wild-type or $\mathrm{CRF}_{2}-/-$ mice $(P<0.0005$; Figure $5 \mathrm{a})$. In contrast, opiate-treated $\mathrm{CRF}_{2}-1-$ mice did not differ from vehicle-treated wild-type or $\mathrm{CRF}_{2}-/-$ mice. Moreover, opiate-treated $\mathrm{CRF}_{2}-I-$ mice made less paw tremors than opiate-treated wild-type mice $(P<0.005$; Figure $5 a)$. We also found a genotype $\times$ opiate treatment interaction effect for the wet dog shake sign $\left(\mathrm{F}_{1,23}=7.68, P<0.05\right)$. Both wildtype and $\mathrm{CRF}_{2}-/-$ mice treated with morphine made more wet dog shakes than vehicle-treated wild-type or $\mathrm{CRF}_{2}-1-$ mice $(P<0.001$; Figure 5b). However, opiate-treated $\mathrm{CRF}_{2}-1-$ mice made less wet dog shakes than opiatetreated wild-type mice $(P<0.0005$; Figure $5 b) . \quad \mathrm{CRF}_{2}$ receptor deficiency did not affect the expression of jumping and sniffing. Neither wild-type nor $\mathrm{CRF}_{2}-1-$ mice treated with vehicle and challenged with naloxone displayed jumping or sniffing. In contrast, naloxone produced reliable levels of jumping in opiate-treated wild-type $(U=0.0$, $P<0.005 v s$ vehicle-treated wild-type mice; Figure $5 c)$ or $\mathrm{CRF}_{2}-I-$ mice $\left(U=10.5, P<0.05\right.$ vs vehicle-treated $\mathrm{CRF}_{2}-/-$ mice; Figure $5 \mathrm{c}$ ). Naloxone also produced reliable levels of sniffing in opiate-treated wild-type $(U=0.0, P<0.005 \mathrm{vs}$ vehicle-treated wild-type mice; Figure $5 \mathrm{~d}$ ) or $\mathrm{CRF}_{2}-/-$ mice $\left(U=3.5, \quad P<0.005\right.$ vs vehicle-treated $\mathrm{CRF}_{2}-\mathrm{I}-$ mice; Figure 5d). Opiate-treated $\mathrm{CRF}_{2}-\mathrm{I}-$ mice did not differ from opiate-treated wild-type mice in the expression of jumping $(U=13.5, P=\mathrm{NS}$; Figure $5 \mathrm{c})$ or sniffing $(U=10.0$, $P=\mathrm{NS}$; Figure $5 \mathrm{~d}$ ). 

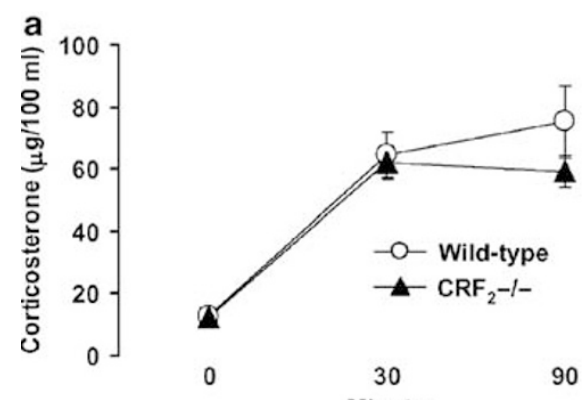

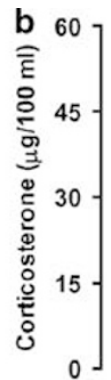

C

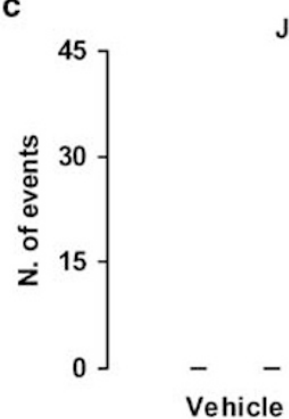

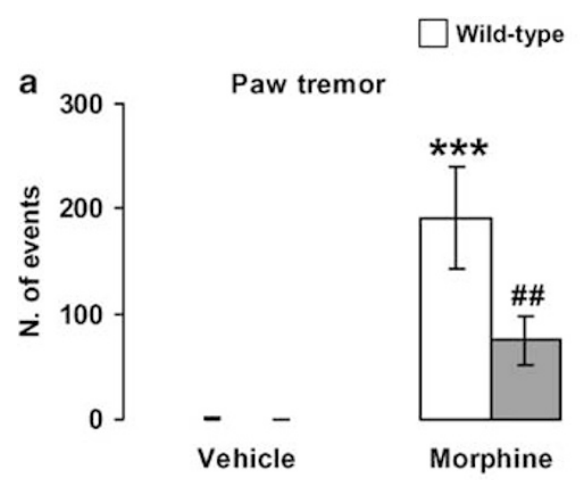

Figure 4 HPA axis responses to opiate dosing and withdrawal. Plasma corticosterone levels displayed by opiate-withdrawn wild-type or $\mathrm{CRF}_{2}-/-$ mice (a) just prior to (0: 12-h opiate withdrawal) and 30 and $90 \mathrm{~min}$ after the last morphine injection and (b) immediately after a 30-min somatic opiate withdrawal test carried out $8 \mathrm{~h}$ after the last morphine injection. During 6 consecutive days, wild-type and $\mathrm{CRF}_{2}-/-$ mice were treated every $12 \mathrm{~h}$ with increasing morphine doses (20-100 mg/kg; i.p.). Values represent mean \pm SEM. $N=6$ per genotype.

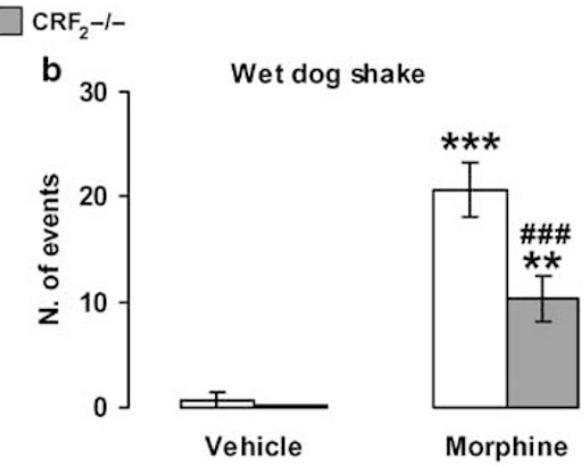

Jump
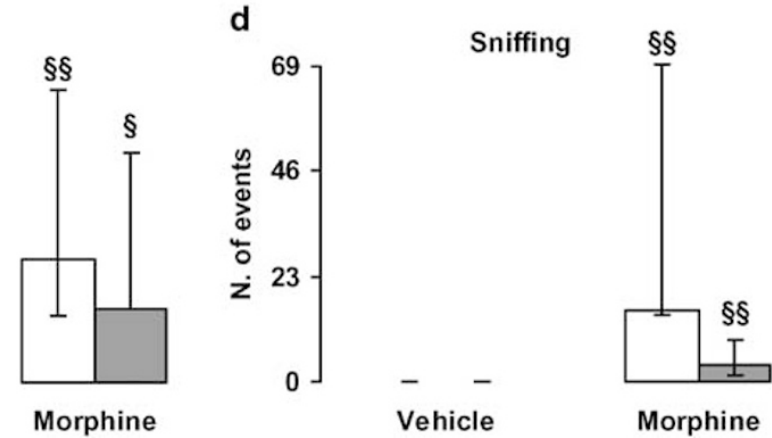

Figure 5 Discrete graded somatic signs of naloxone-precipitated opiate withdrawal. (a) Paw tremors, (b) wet dog shakes, (c) jumps, and (d) sniffing displayed by vehicle- or morphine-treated wild-type or $\mathrm{CRF}_{2}-/$ - mice during a 30-min test carried out immediately after naloxone (I mg/kg, s.c.) dosing. Naloxone was administered $2 \mathrm{~h}$ after the last vehicle or morphine injection. Values represent mean \pm SEM for paw tremor and wet dog shake, and median (lower, upper quartile) for jump and sniffing. $N=6-8$ per group. ${ }^{* *} P<0.00$ I, ${ }^{* * *} * P<0.0005$ vs vehicle-treated mice; ${ }^{\# \#} P<0.005$, ${ }^{\# \#} P<0.0005$ vs morphine-treated wild-type mice; ${ }^{{ }} P<0.05,{ }^{\$} P P<0.005$ vs same genotype vehicle-treated mice.

Evaluation of checked somatic signs of naloxoneprecipitated opiate withdrawal revealed an opiate treatment effect for chewing, body tremor, palpebral ptosis, and piloerection. Opiate-treated wild-type mice displayed more chews $(U=0.0, P<0.005$; Figure $6 \mathrm{a})$, body tremors $(U=0.0$, $P<0.005$; Figure $6 \mathrm{~b})$, palpebral ptoses $(U=3.0, P<0.01$; Figure $6 c)$, and piloerection $(U=0.0, P<0.005$; Figure $6 \mathrm{~d}$ ) than vehicle-treated wild-type mice. Similarly, opiatetreated $\mathrm{CRF}_{2}-/-$ mice displayed more chews $(U=0.0$, $P<0.001$; Figure 6a), body tremors $(U=3.5, P<0.005$; Figure $6 \mathrm{~b})$, palpebral ptoses $(U=7.0, P<0.01$; Figure $6 \mathrm{c}$ ), and piloerection $(U=7.0, P<0.01$; Figure $6 \mathrm{~d})$ than vehicletreated $\mathrm{CRF}_{2}-I-$ mice. Opiate-treated $\mathrm{CRF}_{2}-/-$ mice did not differ from opiate-treated wild-type mice in the expression of chewing $(U=13.5, P=\mathrm{NS})$, body tremor $(U=19.0, P=\mathrm{NS})$, palpebral ptosis $(U=23.5, P=\mathrm{NS})$, and piloerection $(U=20.5, P=\mathrm{NS})$. In the naloxoneprecipitated opiate withdrawal study, neither the genotype nor the opiate treatment affected the expression of the diarrhea sign. Diarrhea events were as follows: for vehicletreated mice: wild-type $=0.0(0.0,0.0), \mathrm{CRF}_{2}-I-=0.0(0.0$, $0.0)$, and for opiate-treated mice: wild-type $=0.0(0.0,1.0)$, $\mathrm{CRF}_{2}-/-=0.0(0.0,1.0)$; median (lower, upper quartile). Also, during the 30-min naloxone-precipitated opiate withdrawal test, the percentage of $\mathrm{BW}$ loss was as follows: for vehicle-treated mice: wild-type $=0.95 \pm 0.4, \mathrm{CRF}_{2}-$ / $-=0.45 \pm 0.1$, and for opiate-treated mice: wild-type $=$ $1.08 \pm 0.4, \mathrm{CRF}_{2}-/-=0.42 \pm 0.3$ (mean $\pm \mathrm{SEM}$ ); analysis of 

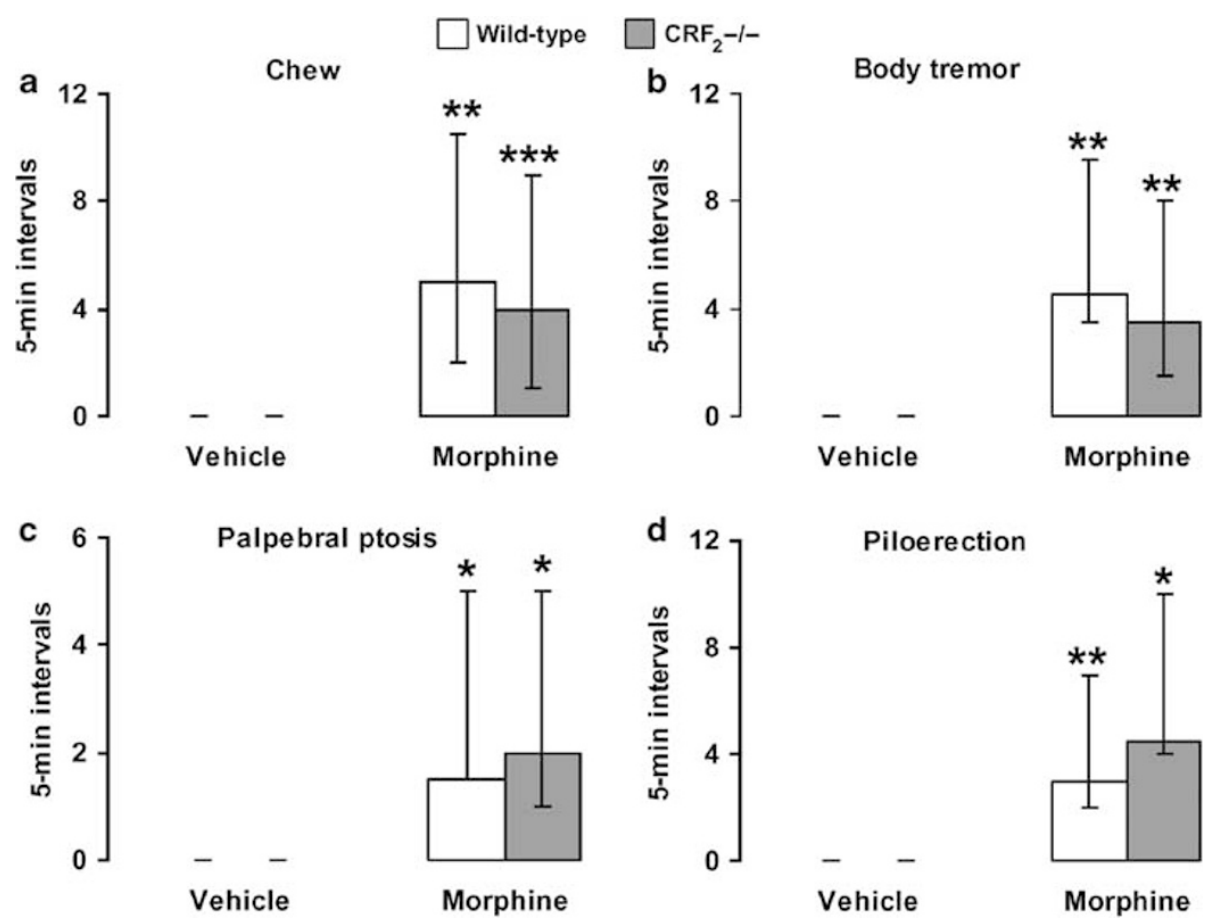

Figure 6 Discrete checked somatic signs of naloxone-precipitated opiate withdrawal. (a) Chews, (b) body tremors, (c) palpebral ptoses, and (d) piloerection displayed by vehicle- or morphine-treated wild-type or $\mathrm{CRF}_{2}-1$ - mice during a 30-min test carried out immediately after naloxone (I mg/ $/ \mathrm{kg}$, s.c.) dosing. Naloxone was administered $2 \mathrm{~h}$ after the last vehicle or morphine injection. Values represent the median (lower, upper quartile). $\mathrm{N}=6-8 \mathrm{per}$ group. $* P<0.01$, $* * P<0.005$, $* * * P<0.00$ I vs same genotype vehicle-treated mice.

the latter parameter revealed no genotype effect $\left(\mathrm{F}_{1,23}=\right.$ 2.67, $P=\mathrm{NS})$, no opiate treatment effect $\left(\mathrm{F}_{1,23}=0.06\right.$, $P=$ NS), and no genotype $\times$ opiate treatment interaction effect $\left(\mathrm{F}_{1,23}=0.04, P=\mathrm{NS}\right)$. Thus, similar to the spontaneous opiate withdrawal study described above, $\mathrm{CRF}_{2}$ receptor deficiency sharply decreased the expression of major somatic signs of opiate withdrawal, such as paw tremor and wet dog shake, also in chronically opiate-treated mice challenged with the opioid receptor antagonist naloxone.

An analysis of global scores revealed a genotype effect $\left(\mathrm{F}_{1,23}=7.33, \quad P<0.05\right), \quad$ an opiate treatment effect $\left(\mathrm{F}_{1,23}=28.78, P<0.0001\right)$, and a genotype $\times$ opiate treatment interaction effect $\left(\mathrm{F}_{1,23}=7.06, P<0.05\right)$. Opiatetreated wild-type mice displayed higher global scores than vehicle-treated wild-type or $\mathrm{CRF}_{2}-I-$ mice $(P<0.0005$; Figure 7). In net contrast, global scores displayed by opiatetreated $\mathrm{CRF}_{2}-/-$ mice did not differ from those of vehicletreated wild-type or $\mathrm{CRF}_{2}-I-$ mice $(P=\mathrm{NS}$; Figure 7$)$. Moreover, opiate-treated $\mathrm{CRF}_{2}-\mathrm{I}-$ mice displayed lower global opiate withdrawal scores than opiate-treated wildtype mice $(P<0.0005$; Figure 7$)$. Thus, the lack of functional $\mathrm{CRF}_{2}$ receptor levels overall decreased the expression of naloxone-precipitated somatic opiate withdrawal signs, reducing global scores of opiate-treated $\mathrm{CRF}_{2}-1-$ mice to drug-naive mice levels.

\section{DISCUSSION}

This report demonstrates, by both a spontaneous opiate withdrawal paradigm recently developed in our laboratory

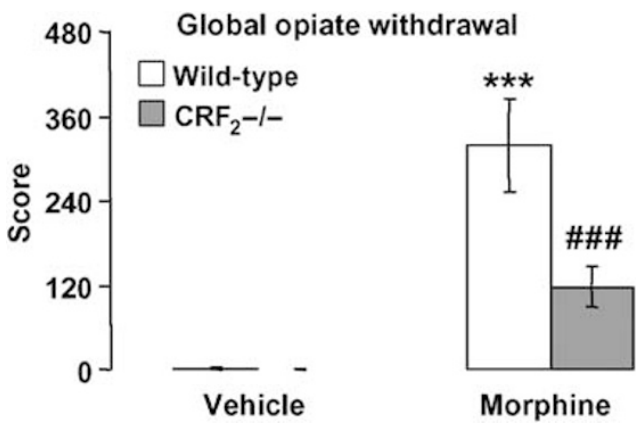

Figure 7 Global score of naloxone-precipitated somatic opiate withdrawal. Comprehensive scores (sum of the somatic sign values) displayed by vehicle- or morphine-treated wild-type or $\mathrm{CRF}_{2}-/$ - mice during a 30min test carried out immediately after naloxone (I mg/ $\mathrm{kg}$, s.c.) dosing. Naloxone was administered $2 \mathrm{~h}$ after the last vehicle or morphine injection. Values represent mean \pm SEM. $N=6-8$ per group. $* * * P<0.0005$ vs vehicle-treated mice. ${ }^{\# \#} P<0.0005$ vs morphine-treated wild-type mice.

(Papaleo and Contarino, 2006) and a classical opioid receptor antagonist-precipitated opiate withdrawal procedure (Matthes et al, 1996), a crucial role for the $\mathrm{CRF}_{2}$ receptor pathway in the somatic expression of opiate withdrawal. In particular, mice lacking functional levels of the $\mathrm{CRF}_{2}$ receptor pathway displayed decreased somatic reactions to the stressful condition of opiate withdrawal, as compared to wild-type mice.

To mimic the clinical setting, in the present study mice were treated with intermittent escalating morphine doses and opiate withdrawal-related somatic signs assessed following 'spontaneous' clearance of the opiate drug from the body. Using such a clinically oriented experimental 
paradigm, we found that $\mathrm{CRF}_{2}-/-$ mice showed lower levels of major somatic signs of opiate withdrawal, such as paw tremor and wet dog shake, than wild-type mice. Genotype differences were observed at several time points, that is, $8-128 \mathrm{~h}$ after the last opiate administration, ruling out a genotype-dependent time-shift in the expression of somatic opiate withdrawal. $\mathrm{CRF}_{2}$ receptor-deficient mice also showed lower global opiate withdrawal scores than wild-type mice, which were evident as soon as $8 \mathrm{~h}$ after the last opiate injection, and lasted at least up to $128 \mathrm{~h}$ following drug discontinuation. We also investigated the impact of $\mathrm{CRF}_{2}$ receptor deficiency upon the somatic expression of opioid receptor antagonist (naloxone)-precipitated opiate withdrawal. Prior to naloxone challenge, mice were repeatedly treated with increasing morphine doses as in the spontaneous opiate withdrawal study. We found that $\mathrm{CRF}_{2}$ receptor deficiency dampened the expression of paw tremor and wet dog shake and decreased global opiate withdrawal scores, a behavioral result very similar to that observed in the spontaneous opiate withdrawal study. Notably, the spontaneous and the opioid receptor antagonist-precipitated opiate withdrawal studies were carried out in two different laboratories (see the Materials and Methods section), strengthening the reliability and significance of our results. Thus, both the spontaneous and the naloxoneprecipitated opiate withdrawal studies reported here clearly indicate that genetic disruption of the $\mathrm{CRF}_{2}$ receptor pathway sharply reduces the severity of major somatic signs of opiate withdrawal, suggesting that activation of the $\mathrm{CRF}_{2}$ receptor pathway may positively modulate the somatic expression of opiate withdrawal.

The present study also provides novel evidence in favor of major differences between spontaneous and opioid receptor antagonist-precipitated opiate withdrawal in mice. In particular, in either wild-type or $\mathrm{CRF}_{2}$ receptor-deficient mice, naloxone increased the expression of almost all of the somatic opiate withdrawal signs examined, as compared to the spontaneous opiate withdrawal condition. Moreover, the opioid receptor antagonist triggered somatic signs, such as piloerection, body tremor, sniffing, and jumping, which were not observed during the spontaneous opiate withdrawal study. Accordingly, previous studies showed that challenging opiate-dependent rats with opioid receptor antagonists induced behavioral signs that greatly differed, in both intensity and type, from those observed in animals undergoing spontaneous opiate withdrawal (Cicero et al, 2002; Houshyar et al, 2004; Linseman, 1977; Mucha et al, 1979; Papaleo and Contarino, 2006; Papaleo et al, 2007; Ruiz et al, 1996).

Genetically engineered mouse models have allowed the identification of distinct and often opposite functions for the two known CRF receptor pathways in HPA axis and affective-like behavioral responses to stress (Bale and Vale, 2004; Contarino and Gold, 2002). In particular, either $\mathrm{CRF}_{1}$ receptor deficiency or functional antagonism of the $\mathrm{CRF}_{1}$ receptor pathway decreased anxiety-like and depressionlike behavior (Contarino et al, 1999; Griebel et al, 2002; Hodgson et al, 2007; Nielsen et al, 2004; Okuyama et al, 1999; Smith et al, 1998; Timpl et al, 1998; Zorrilla et al, 2002). Also, $\mathrm{CRF}_{1}-I-$ mice displayed deficient HPA axis responses to stressful events (Contarino and Papaleo, 2005; Papaleo et al, 2007; Smith et al, 1998; Timpl et al, 1998). In net contrast, genetic disruption of the $\mathrm{CRF}_{2}$ receptor pathway increased the expression of anxiety-like and depression-like behavior, and exacerbated HPA axis responses to an immobilization stress (Bale et al, 2000; Bale and Vale, 2003; Coste et al, 2000, 2006; Kishimoto et al, 2000). Finally, $\mathrm{CRF}_{1}$ and $\mathrm{CRF}_{2}$ receptor pathways were shown to have opposite roles on information processing mechanisms that regulate responses to stressors. In particular, either genetic inactivation or pharmacological antagonism of the $\mathrm{CRF}_{1}$ receptor pathway increased prepulse inhibition (PPI) of defensive startle responses by sensory stimuli, whereas pharmacological antagonism of the $\mathrm{CRF}_{2}$ receptor pathway decreased PPI (Risbrough et al, 2004). Recently, studies also suggested distinct roles for the $\mathrm{CRF}_{1}$ (vs the $\mathrm{CRF}_{2}$ ) receptor pathway in ethanol dependence. In particular, during acute ethanol withdrawal, $\mathrm{CRF}_{1}$ receptor activity was shown to mediate excessive ethanol self-administration in dependent animals, whereas activation of the $\mathrm{CRF}_{2}$ receptor pathway reduced ethanol intake as well as anxiety-like behavior induced by ethanol withdrawal (Funk et al, 2007; Valdez et al, 2004). We have recently reported that genetic inactivation as well as pharmacological antagonism of the $\mathrm{CRF}_{1}$ receptor pathway increased and prolonged the somatic expression of opiate withdrawal (Papaleo et al, 2007). In contrast to $\mathrm{CRF}_{1}$ receptor deficiency, in the present study we demonstrate that $\mathrm{CRF}_{2}$ receptor-deficient mice displayed reduced somatic signs of opiate withdrawal as compared to wild-type mice. Notably, both in our previous and present studies, we used exactly the same experimental paradigm to investigate the role for the $\mathrm{CRF}_{1}$ or the $\mathrm{CRF}_{2}$ receptor pathway in opiate withdrawal. Thus, together with our recent study in $\mathrm{CRF}_{1}$ receptor-null mutant mice (Papaleo et al, 2007), the present results provide initial and compelling evidence of opposite roles for the two known CRF receptor pathways in somatic opiate withdrawal. In particular, following abrupt discontinuation of opiate administration, $\mathrm{CRF}_{1}$ receptor signaling may dampen, whereas the $\mathrm{CRF}_{2}$ receptor pathway may function to facilitate the somatic expression of opiate withdrawal.

The present findings of decreased somatic opiate withdrawal signs in $\mathrm{CRF}_{2}-/-$ mice are in apparent contrast with studies showing that $\mathrm{CRF}_{2}-I-$ mice displayed increased behavioral responses to stressful events (Bale et al, 2000; Bale and Vale, 2003; Coste et al, 2006; Kishimoto et al, 2000). However, in contrast to $\mathrm{CRF}_{1}$ receptors, the role for the $\mathrm{CRF}_{2}$ receptor pathway in stress-responsive circuitry is somewhat less clear. Studies have shown anxiolytic-like effects of $\mathrm{CRF}_{2}$ receptor activation (Valdez et al, 2002a, 2003; Venihaki et al, 2004). Moreover, genetic disruption of the $\mathrm{CRF}_{2}$ receptor pathway resulted in increased anxietylike and depressive-like behaviors (Bale et al, 2000; Bale and Vale, 2003; Coste et al, 2006; Kishimoto et al, 2000). In contrast, other reports suggested a stress-like activity for the $\mathrm{CRF}_{2}$ receptor pathway (Henry et al, 2006; Ho et al, 2001; Radulovic et al, 1999; Risbrough et al, 2003, 2004). It should be pointed out that the in vivo receptor selectivity of the CRF-related peptides and/or peptide doses used in the studies cited above remains uncertain. In the present study, we used a genetic model of $\mathrm{CRF}_{2}$ receptor inactivation, which might provide a level of molecular specificity that is rarely achieved by pharmacological studies. Prior to being 
tested for somatic expression of opiate withdrawal, every $12 \mathrm{~h}$ wild-type and $\mathrm{CRF}_{2}-1-$ mice were repeatedly treated with increasing doses of morphine. The twice-daily partial opiate withdrawal that accompanied our drug regimen may have served as a severe chronic stressor. Accordingly, $12 \mathrm{~h}$ after morphine dosing, rats treated with a morphine regimen similar to that used in the present study displayed stress-like alterations in the brain, HPA axis, and metabolic functions (Houshyar et al, 2004). We also found elevated CRF expression in the paraventricular nucleus of the hypothalamus, a main brain region coordinating HPA axis responses to stress, of opiate-withdrawn wild-type mice treated with the same morphine regimen as that used in the present study (Papaleo et al, 2007). Thus, the present results clearly indicate decreased somatic reactions to the stressful event of opiate withdrawal in $\mathrm{CRF}_{2}$ receptor-deficient mice. However, further studies are needed to better characterize the role for the $\mathrm{CRF}_{2}$ receptor pathway in drug withdrawalrelated stressful conditions.

We recently demonstrated a major role for the HPA axis in behavioral, molecular, and neuroendocrine alterations relevant to the somatic expression of opiate withdrawal (Papaleo et al, 2007). In particular, during the stressful condition of opiate withdrawal, $\mathrm{CRF}_{1}$ receptor-deficient mice showed increased somatic signs as well as profound impairments in the HPA axis and extra-hypothalamic brain stress-responsive circuitry. Interestingly, we found that aberrant behavioral and molecular responses to the stress of opiate withdrawal observed in $\mathrm{CRF}_{1}$ receptor-deficient mice were largely dependent on the HPA axis impairments associated with the $\mathrm{CRF}_{1}$ receptor-null mutation. Accordingly, treatment of the $\mathrm{CRF}_{1}-/-$ mice with non-stressful amounts of corticosterone during repeated intermittent dosing with morphine effectively reduced the somatic signs of opiate withdrawal and restored 'wild-type-like' brain responses to the stressful condition of opiate withdrawal (Papaleo et al, 2007). Most likely, the 'beneficial' effects of exogenous corticosterone observed in the $\mathrm{CRF}_{1}$ receptordeficient mice were due to enduring changes in the HPA system that were taking place throughout the intermittent morphine treatment (Papaleo et al, 2007). Thus, 'normalizing' HPA axis activity during intermittent opiate exposure may effectively reduce the severe somatic consequences of opiate withdrawal. In the present study, we provide initial evidence showing that $\mathrm{CRF}_{2}-/-$ mice displayed an intact HPA axis response to drug-related stressful conditions (opiate dosing and opiate withdrawal). In particular, our results clearly show that $\mathrm{CRF}_{2}-/-$ mice were able to mount relatively high plasma corticosterone responses to either opiate dosing $(48-114 \mu \mathrm{g} / 100 \mathrm{ml})$ or opiate withdrawal $(23-71 \mu \mathrm{g} / 100 \mathrm{ml})$. However, since wild-type and $\mathrm{CRF}_{2}-/-$ mice showed similar plasma corticosterone responses to either opiate dosing or withdrawal, the present findings do not support a role for the HPA axis in the decreased somatic expression of opiate withdrawal displayed by $\mathrm{CRF}_{2}$ receptor-deficient mice.

The results of the present study bear important implications for research aimed at developing novel medications for the opiate withdrawal syndrome. Human and animal studies indicate that avoidance of, and/or escape from, the extremely stressful condition of opiate withdrawal powerfully motivates compulsive heroin-seeking and heroin-taking behavior (Baker et al, 2004; Carrera et al, 1999; Kenny et al, 2006; Lu et al, 2005; Schulteis and Koob, 1996). Here, we report that genetic disruption of the $\mathrm{CRF}_{2}$ receptor pathway sharply reduced the expression of major somatic signs of opiate withdrawal. Notably, under both a clinically relevant spontaneous opiate withdrawal and a classical opioid receptor antagonist-precipitated opiate withdrawal paradigm, mice lacking functional levels of the $\mathrm{CRF}_{2}$ receptor pathway displayed decreased somatic reactions to the stress of opiate withdrawal. These findings unravel a novel role for the $\mathrm{CRF}_{2}$ receptor pathway in opiate withdrawal and suggest new pharmacological strategies for the management of the opiate withdrawal syndrome.

\section{ACKNOWLEDGEMENTS}

We thank Drs Wylie Vale (The Salk Institute, La Jolla, CA, USA) and Antoine Tabarin (Université Victor Segalen Bordeaux 2, Bordeaux, France) for the $\mathrm{CRF}_{2}$ receptor mutant mouse breeders. FP was supported by a postdoctoral fellowship from the Université Victor Segalen Bordeaux 2, Bordeaux, France. AC was supported by the Université Victor Segalen Bordeaux 2, Bordeaux, France. SG and AJR were supported by NIH Grant AA013523. GFK was supported by NIDA Grant DA04043. We also thank Drs Pierre Costet and Marianne Husson for mouse breeding and genotyping, respectively, and Drs Pierre Kitchener and Piervincenzo Piazza for help with the corticosterone experiment. AC would like to dedicate this paper to Professor D Liguoro.

\section{DISCLOSURE/CONFLICT OF INTEREST}

The authors declared that they have no financial conflict of interest.

\section{REFERENCES}

Baker TB, Piper ME, McCarthy DE, Majeskie MR, Fiore MC (2004). Addiction motivation reformulated: an affective processing model of negative reinforcement. Psychol Rev 111: 33-51.

Bale TL, Contarino A, Smith GW, Chan R, Gold LH, Sawchenko PE et al (2000). Mice deficient for corticotropin-releasing hormone receptor-2 display anxiety-like behaviour and are hypersensitive to stress. Nat Genet 24: 410-414.

Bale TL, Vale WW (2003). Increased depression-like behaviors in corticotropin-releasing factor receptor-2-deficient mice: sexually dichotomous responses. J Neurosci 23: 5295-5301.

Bale TL, Vale WW (2004). CRF and CRF receptors: role in stress responsivity and other behaviors. Annu Rev Pharmacol Toxicol 44: 525-557.

Carrera MR, Schulteis G, Koob GF (1999). Heroin self-administration in dependent Wistar rats: increased sensitivity to naloxone. Psychopharmacology (Berl) 144: 111-120.

Cicero TJ, Nock B, Meyer ER (2002). Gender-linked differences in the expression of physical dependence in the rat. Pharmacol Biochem Behav 72: 691-697.

Contarino A, Dellu F, Koob GF, Smith GW, Lee KF, Vale W et al (1999). Reduced anxiety-like and cognitive performance in mice lacking the corticotropin-releasing factor receptor 1. Brain Res 835: 1-9. 
Contarino A, Gold LH (2002). Targeted mutations of the corticotropin-releasing factor system: effects on physiology and behavior. Neuropeptides 36: 103-116.

Contarino A, Papaleo F (2005). The corticotropin-releasing factor receptor-1 pathway mediates the negative affective states of opiate withdrawal. Proc Natl Acad Sci USA 102: 18649-18654.

Coste SC, Heard AD, Phillips TJ, Stenzel-Poore MP (2006). Corticotropin-releasing factor receptor type 2-deficient mice display impaired coping behaviors during stress. Genes Brain Behav 5: 131-138.

Coste SC, Kesterson RA, Heldwein KA, Stevens SL, Heard AD, Hollis $\mathrm{JH}$ et al (2000). Abnormal adaptations to stress and impaired cardiovascular function in mice lacking corticotropinreleasing hormone receptor-2. Nat Genet 24: 403-409.

Erb S, Shaham Y, Stewart J (1998). The role of corticotropinreleasing factor and corticosterone in stress- and cocaineinduced relapse to cocaine seeking in rats. J Neurosci 18: 5529-5536.

Funk CK, Zorrilla EP, Lee MJ, Rice KC, Koob GF (2007). Corticotropin-releasing factor 1 antagonists selectively reduce ethanol self-administration in ethanol-dependent rats. Biol Psychiatry 61: 78-86.

Gellert VF, Holtzman SG (1978). Development and maintenance of morphine tolerance and dependence in the rat by scheduled access to morphine drinking solutions. J Pharmacol Exp Ther 205: 536-546.

Gonzalez G, Oliveto A, Kosten TR (2004). Combating opiate dependence: a comparison among the available pharmacological options. Expert Opin Pharmacother 5: 713-725.

Griebel G, Simiand J, Steinberg R, Jung M, Gully D, Roger P et al (2002). 4-(2-Chloro-4-methoxy-5-methylphenyl)- $N$-[(1S)-2cyclopropyl-1-(3-fluoro-4-methylphenyl)ethyl]5-methyl- $N$-(2-propynyl)-1,3-thiazol-2-amine hydrochloride (SSR125543A), a potent and selective corticotrophin-releasing factor(1) receptor antagonist. II. Characterization in rodent models of stressrelated disorders. J Pharmacol Exp Ther 301: 333-345.

Hauger RL, Grigoriadis DE, Dallman MF, Plotsky PM, Vale WW, Dautzenberg FM (2003). International union of pharmacology. XXXVI. Current status of the nomenclature for receptors for corticotropin-releasing factor and their ligands. Pharmacol Rev 55: 21-26.

Heinrichs SC, Menzaghi F, Pich EM, Baldwin HA, Rassnick S, Britton KT et al (1994). Anti-stress action of a corticotropinreleasing factor antagonist on behavioral reactivity to stressors of varying type and intensity. Neuropsychopharmacology 11: $179-186$.

Henry B, Vale W, Markou A (2006). The effect of lateral septum corticotropin-releasing factor receptor 2 activation on anxiety is modulated by stress. J Neurosci 26: 9142-9152.

Ho SP, Takahashi LK, Livanov V, Spencer K, Lesher T, Maciag C et al (2001). Attenuation of fear conditioning by antisense inhibition of brain corticotropin releasing factor-2 receptor. Brain Res Mol Brain Res 89: 29-40.

Hodgson RA, Higgins GA, Guthrie DH, Lu SX, Pond AJ, Mullins DE et al (2007). Comparison of the V1b antagonist, SSR149415, and the CRF1 antagonist, CP-154,526, in rodent models of anxiety and depression. Pharmacol Biochem Behav 86: 431-440.

Houshyar H, Manalo S, Dallman MF (2004). Time-dependent alterations in mRNA expression of brain neuropeptides regulating energy balance and hypothalamo-pituitary-adrenal activity after withdrawal from intermittent morphine treatment. J Neurosci 24: 9414-9424.

Kenny PJ, Chen SA, Kitamura O, Markou A, Koob GF (2006). Conditioned withdrawal drives heroin consumption and decreases reward sensitivity. J Neurosci 26: 5894-5900.

Kishimoto T, Radulovic J, Radulovic M, Lin CR, Schrick C, Hooshmand $\mathrm{F}$ et al (2000). Deletion of crhr2 reveals an anxiolytic role for corticotropin-releasing hormone receptor-2. Nat Genet 24: 415-419.

Kreek MJ, LaForge KS, Butelman E (2002). Pharmacotherapy of addictions. Nat Rev Drug Discov 1: 710-726.

Linseman MA (1977). Naloxone-precipitated withdrawal as a function of the morphine-naloxone interval. Psychopharmacology (Berl) 54: 159-164.

$\mathrm{Lu} \mathrm{L}$, Chen H, Su W, Ge X, Yue W, Su F et al (2005). Role of withdrawal in reinstatement of morphine-conditioned place preference. Psychopharmacology (Berl) 181: 90-100.

Matthes HW, Maldonado R, Simonin F, Valverde O, Slowe S, Kitchen I et al (1996). Loss of morphine-induced analgesia, reward effect and withdrawal symptoms in mice lacking the muopioid-receptor gene. Nature 383: 819-823.

Mucha RF, Kalant H, Linseman MA (1979). Quantitative relationships among measures of morphine tolerance and physical dependence in the rat. Pharmacol Biochem Behav 10: 397-405.

Muller MB, Zimmermann S, Sillaber I, Hagemeyer TP, Deussing JM, Timpl P et al (2003). Limbic corticotropin-releasing hormone receptor 1 mediates anxiety-related behavior and hormonal adaptation to stress. Nat Neurosci 6: 1100-1107.

NIDA (2005). Monitoring the future: national results on adolescent drug use. Available at http://www.monitoringthefuture.org. Accessed May 2007.

Nielsen DM, Carey GJ, Gold LH (2004). Antidepressant-like activity of corticotropin-releasing factor type-1 receptor antagonists in mice. Eur J Pharmacol 499: 135-146.

O’Brien CP (1996). Drug addiction and drug abuse. In: Hardman JG, Limbird LE (eds). Goodman and Gilman's The Pharmacological Basis of Therapeutics. McGraw-Hill: New York. pp 557-577.

OEDT (2006). European Monitoring Centre for Drugs and Drug Addiction. Annual Report 2006. Available at http://www.emcdda. europa.eu. Accessed May 2007.

Okuyama S, Chaki S, Kawashima N, Suzuki Y, Ogawa S, Nakazato A et al (1999). Receptor binding, behavioral, and electrophysiological profiles of nonpeptide corticotropin-releasing factor subtype 1 receptor antagonists CRA1000 and CRA1001. J Pharmacol Exp Ther 289: 926-935.

Papaleo F, Contarino A (2006). Gender- and morphine dose-linked expression of spontaneous somatic opiate withdrawal in mice. Behav Brain Res 170: 110-118.

Papaleo F, Kitchener P, Contarino A (2007). Disruption of the CRF/CRF(1) receptor stress system exacerbates the somatic signs of opiate withdrawal. Neuron 53: 577-589.

Radulovic J, Ruhmann A, Liepold T, Spiess J (1999). Modulation of learning and anxiety by corticotropin-releasing factor (CRF) and stress: differential roles of CRF receptors 1 and 2. J Neurosci 19: 5016-5025.

Risbrough VB, Hauger RL, Pelleymounter MA, Geyer MA (2003). Role of corticotropin releasing factor (CRF) receptors 1 and 2 in CRF-potentiated acoustic startle in mice. Psychopharmacology (Berl) 170: 178-187.

Risbrough VB, Hauger RL, Roberts AL, Vale WW, Geyer MA (2004). Corticotropin-releasing factor receptors CRF1 and CRF2 exert both additive and opposing influences on defensive startle behavior. J Neurosci 24: 6545-6552.

Rivier C, Vale W (1983). Modulation of stress-induced ACTH release by corticotropin-releasing factor, catecholamines and vasopressin. Nature 305: 325-327.

Ruiz F, Fournie-Zaluski MC, Roques BP, Maldonado R (1996). Similar decrease in spontaneous morphine abstinence by methadone and RB 101, an inhibitor of enkephalin catabolism. Br J Pharmacol 119: 174-182.

Sarnyai Z, Biro E, Gardi J, Vecsernyes M, Julesz J, Telegdy G (1995). Brain corticotropin-releasing factor mediates 'anxietylike' behavior induced by cocaine withdrawal in rats. Brain Res 675: 89-97. 
Schulteis G, Koob GF (1996). Reinforcement processes in opiate addiction: a homeostatic model. Neurochem Res 21: 1437-1454.

Shaham Y, Shalev U, Lu L, De Wit H, Stewart J (2003). The reinstatement model of drug relapse: history, methodology and major findings. Psychopharmacology (Berl) 168: 3-20.

Smith GW, Aubry JM, Dellu F, Contarino A, Bilezikjian LM, Gold LH et al (1998). Corticotropin releasing factor receptor 1-deficient mice display decreased anxiety, impaired stress response, and aberrant neuroendocrine development. Neuron 20: 1093-1102.

Stinus L, Cador M, Zorrilla EP, Koob GF (2005). Buprenorphine and a CRF1 antagonist block the acquisition of opiate withdrawal-induced conditioned place aversion in rats. Neuropsychopharmacology 30: 90-98.

Timpl P, Spanagel R, Sillaber I, Kresse A, Reul JM, Stalla GK et al (1998). Impaired stress response and reduced anxiety in mice lacking a functional corticotropin-releasing hormone receptor 1 . Nat Genet 19: 162-166.

Valdez GR, Inoue K, Koob GF, Rivier J, Vale W, Zorrilla EP (2002a). Human urocortin II: mild locomotor suppressive and delayed anxiolytic-like effects of a novel corticotropin-releasing factor related peptide. Brain Res 943: 142-150.
Valdez GR, Roberts AJ, Chan K, Davis H, Brennan M, Zorrilla EP et al (2002b). Increased ethanol self-administration and anxietylike behavior during acute ethanol withdrawal and protracted abstinence: regulation by corticotropin-releasing factor. Alcohol Clin Exp Res 26: 1494-1501.

Valdez GR, Sabino V, Koob GF (2004). Increased anxiety-like behavior and ethanol self-administration in dependent rats: reversal via corticotropin-releasing factor-2 receptor activation. Alcohol Clin Exp Res 28: 865-872.

Valdez GR, Zorrilla EP, Rivier J, Vale WW, Koob GF (2003). Locomotor suppressive and anxiolytic-like effects of urocortin 3, a highly selective type 2 corticotropin-releasing factor agonist. Brain Res 980: 206-212.

Venihaki M, Sakihara S, Subramanian S, Dikkes P, Weninger SC, Liapakis $\mathrm{G}$ et al (2004). Urocortin III, a brain neuropeptide of the corticotropin-releasing hormone family: modulation by stress and attenuation of some anxiety-like behaviours. J Neuroendocrinol 16: 411-422.

Zorrilla EP, Valdez GR, Nozulak J, Koob GF, Markou A (2002). Effects of antalarmin, a CRF type 1 receptor antagonist, on anxiety-like behavior and motor activation in the rat. Brain Res 952: 188-199.

Supplementary Information accompanies the paper on the Neuropsychopharmacology website (http://www.nature.com/npp) 